\title{
Társas kapcsolatok korunk iskolájában
}

\section{F. Lassú Zsuzsa - Serfőző Mónika}

Eötvös Loránd Tudományegyetem, Tanító- és Óvóképző Kar, Neveléstudományi Tanszék

\begin{abstract}
A társadalmi átalakulások, a technológiai fejlödés, a globalizáció, közvetve és közvetlenül is hat a gyermekekre. Jelen tanulmányban a társas kapcsolatok egyes, a mai közbeszédben hangsúlyossá vált jelenségeit járjuk körül, kiemelve a kihívásokra adott intézményes válaszokat, jó gyakorlatokat. Áttekintjük a középső gyermekkor fejlődési sajátosságait, melyek a társas kapcsolatok alakulását befolyásolják. Tárgyaljuk az elfogadottság, népszerüség valamint a kirekesztés, zaklatás jelenségeit, és az ezeket alakitó egyéni és intézményi jellemzőket. Végül bemutatunk néhány olyan európai kezdeményezést, mely a pozitív társas közeg kialakítását támogatja.
\end{abstract}

Kulcsszavak: iskoláskori társas kapcsolatok, népszerüség, zaklatás, támogató programok

„Ezek a mai fiatalok!” - ez az ismerős szlogen évtizedek óta visszatérően jelen van a mindenkori gyermekekröl és serdülőkről szóló magán- és közbeszédben. A mai gyerekek nem tudnak játszani, nem tudnak viselkedni, nem tudnak köszönni, nem tudnak normálisan felöltözni, nem tudnak kulturáltan enni, ... és még sorolhatnánk, mi mindent nem tudnak a felnőttek szerint - minden korban, minden kultúrában. Hogy igazak-e ezek a vádak, nem tudjuk bizonyosan, mert soha senki nem vizsgálta a tudomány módszereivel, longitudinális összehasonlító kutatásban a köszönés vagy „normális” öltözködés gyermekekre jellemző mintázatát. Annyit biztosra vehetünk, hogy a társadalmi átalakulások, a technológiai fejlődés, a globalizáció, vagyis a mindent átható és az élő organizmusokra jellemző folyamatos VÁLTOZÁS hat a gyermekekre. Ez a hatás közvetlen, amennyiben direkt módon a gyermeket célzó folyamatok eredményeként jön létre - ilyen például a gyermeki jogok érvényesítése, a nevelői módszerek változása vagy a köznevelés rendszerének átalakítása. Ugyanakkor számos közvetett hatás is befolyásolja a gyermekek viselkedését, fejlődését, mint a családok strukturális vagy funkcionális változásai, az iskolai vagy a tágabb lakókörnyezet változásai, melyek szintén külső folyamatok által befolyásoltak (pl. gazdasági válság, munkanélküliség, jogi környezet változása, természeti vagy ember okozta katasztrófák stb.). Ebbe a folyamatosan változó ökológiai környezetbe ágyazottan fejlődik és vele szükségszerüen együtt változik a gyermek (ld. Bronfenbrenner, 1979). Jelen tanulmányban a társas kapcsolatok egyes, a mai közbeszédben hangsúlyossá vált jelenségeit, elsősorban a népszerüséget és a zaklatást járjuk körül, kiemelve a kihívásokra adott intézményes válaszokat, jó gyakorlatokat. 


\section{A társas kapcsolatokat meghatározó fejlődési sajátosságok a középső és késői gyermekkorban ${ }^{1}$}

Az egyik jelentős változás, amely a társas kapcsolatok alakulásával szorosan összefügg a középső gyermekkorban bekövetkező én-fejlődés. Az előző szakasz konkrét, fizikai jellemzőkre fókuszáló önjellemzése átalakul, 6-12 éves kor között a gyermekek egyre inkább lélektani jellemzőkkel írják le önmagukat, pl. segítőkész, kedves, népszerü. Az önjellemzés középpontjában a megváltozott élettér áll - a gyermekek önmagukat főként a kitágult és egyre fontosabbá váló társas térben elhelyezve szemlélik, társaikkal kapcsolatban és velük összehasonlítva definiálják (Harter, 2006). Diane Ruble és munkatársai (1980) kutatásukban gyermekek önértékelését vizsgálták a társas összehasonlítás és visszajelzés függvényében. A gyermekeknek először egy nehéz feladatot kellett megoldani, majd visszajelzést kaptak a saját és kortársaik teljesítményéröl. Ezután a gyermekektől önjellemzést kértek. Hét éves kor alatt a gyermekek többségének önjellemzését nem befolyásolta a többiek teljesítményéről kapott visszajelzés, az ennél idősebb gyermekek azonban elkezdtek növekvő figyelemmel tekinteni a társas összehasonlításból származó információra, és ez módosította önmagukról alkotott képüket. Minél fontosabbá válik egy társadalomban a teljesítmény, annál inkább és annál korábban lesz hangsúlyos a gyermeknevelésben is a másokkal való összevetés, a verseny és a teljesítmény folyamatos értékelése. Ennek egyik következménye, hogy a gyermekeknek csökken az önértékelése az iskolai időszak alatt (Blumenfeld, et al. 1981, idézi Santrock, 2009).

Mások megértése szintén nagy fejlődésen megy keresztül a középső és késői gyermekkorban. Ennek kognitív alapja az un. társas nézőpont-átvétel, mely a Piaget által leírt decentrálás képességén alapul (Inhelder és Piaget, 1967). Az egynél több nézőpont/szempont/dimenzió egyszerre történő figyelembe vétele a hét éves kor körül induló konkrét műveleti gondolkodás jellemzője, melynek társas következménye, hogy a gyermek képessé válik társai nézőpontját felismerni és figyelembe venni. Az egocentrizmus csökkenése és az ezzel járó empatikus viszonyulás, valamint a „társas nézőpontok koordinációja" képességének kialakulása azonban nem hirtelen, fokozatmentesen bekövetkező történés a gyermekek életében. Selman és munkatársai kutatásai alapján a középső gyermekkorban a gyerekek fokozatosan megértik, hogy mások másként látják a dolgokat, mivel esetleg más információval, szándékokkal és értékekkel rendelkeznek, mint ők (Selman és Byrne, 1974). A nézőpontváltás képessége a proszociális vagy antiszociális attitüdök és viselkedés közötti döntés alapja. Amennyiben a gyermek képes a másik nézőpontját figyelembe venni, kevésbé valószínű, hogy agresszívan vagy elutasítóan viselkedik a stresszhelyzetekben, sokkal inkább képes a másikkal együttérezni és kész rajta segíteni. Ezzel egyidejüleg ugyanakkor növekszik a gyermek azon képessége is, hogy mások véleményét, ítéleteit vagy önjellemzését kétségbe vonja, különösen, ha azok egyoldalúan pozitívnak tűnnek. A 10-11 évesek már nem hiszik el feltétel nélkül, ha valaki önmagát okosnak, kedvesnek, őszintének írja le, bár ez a kételkedés az önjellemzés kulturális elvárásainak függvénye. A kínai gyerekek nyugati társaikhoz viszonyítva sokkal inkább várják el társaiktól a szerénységet, mivel ez kultúrájukban fontos erény (Heyman, Fu és Lee, 2008).

\footnotetext{
1 A korai és középső gyermekkor kifejezések használatával a nemzetközi szakirodalmi definíciókat követjük. Az UNESCO meghatározásában a korai gyermekkor a 0-8 év, a középső gyermekkor pedig a 6-12 év közötti időszak. A fejlődéslélektani írások általában ezt a szakaszolást követik.
} 
A társas kapcsolatokban való részvétel sikeressége, a beilleszkedés és együttmüködés képessége az érzelmi fejlődés által is meghatározott. A középső gyermekkorban a gyermekek egyre inkább képesek saját és mások érzelmeit felismerni, megérteni és differenciáltan átélni olyan összetett érzéseket, mint a büszkeség vagy a szégyen (Thompson, 1991). A gyermek egyre inkább felismeri az érzelmek szabályozásának képességét, és az idegrendszeri éréssel megtámogatott érzelem-reguláció egyre inkább megvédi a társas kapcsolatokat romboló agressziótól, dühkitörésektől, az érzelmek elárasztásától. Ezzel összefüggésben a növekvő gyermek egyre inkább képes saját és mások érzelmeinek okát helyesen azonosítani, ezáltal felelősséget vállalni tetteiért. Fokozatosan képessé válik a fejlett empátia érzésére, azáltal, hogy nem csak átérzi a másik érzéseit, de képes a negatív érzéseket csökkentő viselkedést eltervezni és kivitelezni (vigasztalás, kiengesztelés, jóvátétel). Az érzelem-szabályozás képessége azonban az életkori fejlettségen túl a gyermek temperamentumának és a társas környezetnek az együttes hatásán alapul.

\section{A kortárs kapcsolatok}

Az iskoláskorú gyermekek társas kapcsolatainak elsődleges színtere a család (lakóhely) és az iskola. Mivel a gyermekek éberen töltött idejük legnagyobb részét az iskolában töltik, így társas kompetenciáik és kapcsolataik legfőbb alakítója ebben az életkorban az iskolai közeg, az itt szerzett tapasztalatok, megerősítések és kudarcok.

Az iskolai osztály egykorú gyermekek csoportja, akiket azonban a családi köteléktől eltérő (kevésbé intim és egymásra utalt) kapcsolatok jellemeznek. Az osztályok létszáma ${ }^{2}$ ma sok iskolában magasabb az intimitást és szoros együttmüködést lehetővé tevő kiscsoport létszámánál (max. 15-20 fő). Az osztályokban a gyermekek nagyon sokfélék lehetnek, személyiségüket, képességeiket, érdeklődésüket és családi hátterüket tekintve egyaránt. A kortársak közötti interakciók így sokkal inkább a nagy csoporton belüli kis csoportokban zajlanak, szükségszerü a klikkesedés, az alcsoportokra bomlás. Az osztályokat ugyanakkor egységben kezeljük, a nevelési célok által vezérelt fejlesztési folyamatok sikerességet a pedagógusok az osztály egészére vonatkoztatva értékelik Az osztály csoportszerkezete, a társas háló ezért a mai napig gyakran vizsgált terület, legközkedveltebb vizsgálati eszköze a szociometria (Mérei, 1996; Mészáros, 1998).

\section{A kedveltség és a népszerüség}

Az a tény, hogy a kortársak visszajelzései, a kedveltség és elfogadottság érzése a középső és késői gyermekkor egyik legfontosabb tényezője az iskolai beilleszkedés és jóllét szempontjából régóta elismert (Parker és Gottman, 1989), a népszerüség és kedveltség összetevőinek, mint a társas beilleszkedés meghatározóinak természete és egymással való kapcsolata ugyanakkor az utóbbi évtizedekben vált kutatási témává (Lease, Kennedy és Axelrod, 2002). A közelmúlt kutatásai feltárták, hogy a kedveltség ténye (melyet a szociometriai vizsgálatok igazolnak) és az észlelt népszerüség (az arra a kérdésre adott válasz, hogy „Szerinted ki a népszerủ az osztályban?”) nem minden esetben esnek egy-

\footnotetext{
2 A 2012/2013-as tanévben az országos átlag 20 fö/osztály az általános iskolában, azonban Budapest népszerü iskoláiban nem ritka a 30 fős osztálylétszám az alsó tagozaton (Statisztikai Tájékoztató, Oktatási Évkönyy. EEM 2013.)
} 
be ${ }^{3}$. Néhány gyermeket társaik népszerünek tartanak, holott a szociometriai vizsgálatok ezt nem támasztják alá, illetve a társak által népszerünek ítélt gyerekeket (föleg serdülőkorban) az elutasított gyerekek jellemzésére használt tulajdonságokkal írnak le a többiek (Parkhurst és Hopmeyer, 1998; Buskirk, Rubin, Burgess, Booth-LaForce és RoseKrasnor, 2004, idézi Parker et al., 2006). Az igazán kedvelt, szociometriai pozíciójuk alapján „kedvelt” gyerekek kedvesek és segítőkészek (Newcomb, Bukowski és Pattee, 1993), míg a „népszerűnek tartott” (menő) fiatalok „vagányak, dominánsak, bevállalósak" de nem feltétlenül kedveltek a társaik által (Adler és Adler, 1998). Ezen eredmények nyomán a kutatókat elkezdte érdekelni a népszerüség jelentése, és arra jutottak, hogy a gyermekek szemében népszerủ társak a proszociális és antiszociális vonások és viselkedésmódok egyedi keverékével jellemezhetők, s ez utóbbiak miatt nem feltétlenül kedveltek. A népszerünek tartott és a ténylegesen népszerü (kedvelt) gyerekek viselkedési profilját összehasonlítva Rubin és munkatársai (1998, idézi Cillessen és Rose, 2005) hasonlóságokat és különbségeket is találtak a két csoport között (a két csoport részben átfedi egymást). Mindkét csoportra jellemző volt a segítőkészség, a proszociális viselkedés, azonban amíg a szociometriai kedveltség alacsony agresszióval járt, addig az észlelt népszerüség pozitívan korrelált az agresszió mértékével, mind a nyílt, mind a kapcsolati agresszió formában (pletyka, kirekesztés, negligálás).

Nem minden népszerűnek tartott gyermek agresszív. Rodkin, Farmer, Pearl és Van Acker (2000) két alcsoportot azonosítottak a népszerünek tartott fiúk körében. A „mintagyerekek” alcsoportjába azok a népszerünek tartott gyerekek tartoztak, akik átlag felett barátságosak és kevéssé agresszívek voltak, míg a „kemény fiúk” alcsoportját olyan népszerūnek tartott gyerekek alkották, akik átlag feletti nyílt agresszióval és átlagos barátságossággal jellemezhetők. Az, hogy egy gyermekcsoportban melyik alcsoport válik dominánssá, az adott csoport értékrendjétől, társas klímájától függ. Ezen tényezőket a későbbiekben tárgyaljuk.

Felvetődik a kérdés, hogy melyek lehetnek az észlelt népszerűség és agresszió együttjárásának a magyarázó elvei. Cillessen és Rose (2005) szerint a népszerūnek tartott gyermekek és fiatalok arra használják az agressziót, hogy népszerüségüket megvédjék vagy növeljék. A kutatási adatok támogatják ezt a feltételezést, mivel eredményeik szerint a népszerünek tartott fiatalok agressziója összefügg a társas pozíciójukat ért vélt vagy valós támadással. Külön érdekesek azok a kutatási eredmények, melyek a népszerünek tartott fiatalok manipulatív társas kompetenciáját tárták fel, melynek segítségével a hatalmi pozíció megőrzése vagy erősítése céljából a helyzet kívánalmainak megfelelően alkalmazták a proszociális és az antiszociális viselkedésformákat (Hawley, 2003). Az ilyen „népszerü manipulátorok” agressziójára sokkal inkább jellemző a kapcsolati, mint a nyílt agresszív viselkedésformák használata, melyeket sokkal kevésbé lehet rejtetten, manipulatív céllal bevetni.

Ez a képesség, mely az agresszió használatával támogatja a népszerüség kialakítását és fenntartását a nem és az életkor függvényében változik. Fiatalabb, 9-11 éves gyermekek körében nem találtak együttjárást az agresszív viselkedés és a népszerüség között, 12 éves kortól azonban a kognitív fejlődéssel párhuzamosan alakuló társas kompetenciák lehetővé teszik, hogy a fiatalok az agressziót a népszerüség növelésére használják. A népszerüség és kapcsolati agresszió pozitív korrelációja ebben az életkorban erősebb a lányok, mint a fiúk körében (LaFontana és Cillessen, 2002; Cillessen és Mayeux, 2004; Rose, Swenson és Waller, 2004).

\footnotetext{
3 A kutatók az előbbit szociometriai az utóbbit észlelt népszerüség fogalommal írják le.
} 
A népszerűség két típusa (a kedvelt és a nem kedvelt népszerü) és az alkalmazkodás kapcsolatát vizsgálva egyértelmű a szociometriai népszerüség és a magas szintü alkalmazkodás együttjárása - a társak által elfogadott, kedvelt fiatalok érzelmileg magas szintü alkalmazkodással és minőségi baráti kapcsolatokkal jellemzettek (Rubin, Bukowski és Parker, 1998). Vajon igaz-e ugyanez a népszerünek tartott, ugyanakkor gyakran agresszív fiatalokra? Két egymásnak ellentmondó feltételezéssel élhetünk. Egyrészt az agresszió elutasításhoz vezet, így ronthatja az alkalmazkodás szintjét, másrészt azonban az elért magas státusz, még ha agresszív eszközökkel is társul, az alkalmazkodás és beilleszkedés jó előrejelzője lehet. Cillessen és Rose (2005) ezért azt feltételezték, hogy a népszerünek tartott fiatalok serdülökorban a kivívott magas státuszt úgy tudják megszerezni, ha jól alkalmazkodnak, azonban kilépve a serdülőkorból, egy másik közegben megfizethetik az agresszió árát. $A z$, hogy átkerülve egy másik társas térbe, megőrzik-e népszerüségüket, azon a képességen múlik, hogy képesek-e az új közegben annak kívánalmaihoz illeszteni a proszociális és domináns/agresszív viselkedésformák egyensúlyát. Ennek bizonyítására azonban longitudinális vizsgálatok szükségesek.

Rose és Swenson (2009) megvizsgálták a népszerünek tartott serdülők érzelmi alkalmazkodását, valamint az agresszióval összefüggésben megjelenő internalizáló tüneteiket. Feltételezték, hogy amennyiben az agresszió elutasító választ vált ki a környezetből (kirekesztés, büntetés), akkor az agresszorban internalizáló tünetek (szorongás, önértékelés csökkenés, depresszió) jelenhetnek meg, melyek viselkedésének megváltoztatására motiválják. Kutatási eredményeik azonban élesen elváltak a nyílt és kapcsolati agresszió, valamint a magas és alacsony státusz alapján. A manipulatív, kapcsolati agresszió, melynek alapja a jó társas készség, a kortársakban elismerést válthat ki, és magas státuszhoz vezethet. $A z$ a serdülő, akit társai népszerūnek tartanak, és kapcsolatilag agresszív (manipulatív, kirekesztő, pletykát terjesztő, stb.), ezzel státuszát nem csökkenti, hanem általában növeli, így internalizáló tünetek sem jelennek meg nála. Mivel nem szorong, sőt sikerélményei vannak, így viselkedése mindaddig fennmarad, amíg társaitól viselkedésére elismerést kap. Különösen így van ez a népszerünek tartott lányok esetében, akiknek a kapcsolati agressziója a fiúk szemében még növeli is népszerüségüket (Smith, Rose és Schwartz-Mette, 2010). Mivel ezek a fiatalok általában elég okosak ahhoz, hogy agressziójuk rejtve maradjon, így a felnőttektől sem kapnak büntetést, elmarasztalást.

Az alacsony státuszú serdülőknek, akik kevésbé tehetségesek agressziójuk leplezésében, ugyanakkor nem bocsátják meg a kapcsolati agressziót, ami ezáltal internalizáló problémákhoz, érzelmi alkalmazkodási zavarokhoz vezet. A nyílt fizikai vagy verbális agresszió mindkét csoportnál elutasítással járhat - ezt ugyanis sokkal kevésbé lehet rejtve, manipulatív céllal müvelni.

Mindezek az adatok egyértelműen megmutatják annak szükségességét, hogy a szülők és nevelők jobban figyeljenek oda a magas státuszú, népszerünek tartott, „véleményvezér" fiatalokra, akik élen járhatnak a társas klíma alakításában.

\section{Zaklatás az iskolában}

Az iskolai (kortárs) zaklatás a társas kapcsolatok sötét oldala, a kapcsolati vagy nyílt (verbális és/vagy fizikai) agresszió speciális megjelenése, mely tartósan néhány kiszemelt áldozatra irányul, szándékosan fizikai vagy lelki sérelmet okozva, és kihasználva a felek közötti hatalmi és erőviszonyok egyensúlytalanságát (Buda, 2008, 2009; Olweus, 1999). A rendszeres és módszeres iskolai zaklatás inkább jelenik meg felső tagozatban és középiskolában, mint alsóban, noha az áldozat maga lehet egy fiatalabb gyerek. Ennek 
oka, hogy a kortársak közötti zaklatás státuszhierarchiát és fejlett kapcsolati készségeket kíván, melyek az életkor és a csoportalakulás folyamatának előrehaladtával fejlődnek. Szintén fejlődési sajátosságok, elsősorban a serdülés tehető felelőssé a szexuális érdeklödés fokozódásáért a tizenéves korban, mely az azonos nemüek közötti versengést fokozza a koedukált iskolai közegben. Ennek fényében majdhogynem elkerülhetetlenek a kortársak közötti konfliktusok, melyek azonban csak ritkán válnak zaklatássá. Hazánkban a kutatások adatai szerint 14-15\%-ra tehető azoknak a gyerekeknek az aránya, akik hetente, rendszeresen valamilyen zaklatás áldozataivá válnak, és a gyerekek 13-27\%-a lesz elkövető (Buda, 2008). A WHO iskoláskorúak egészségmagatartását vizsgáló kutatássorozatában, a 2005/2006-os HBSC adatfelvételen a 11 éves magyar lányok 10\%-a, a fiúk 9\%-a számolt be arról, hogy az elmúlt hónapokban legalább kétszer volt zaklatás áldozata. A 2009/2010-es HBSC adatfelvételen ezek az adatok némileg módosultak, ekkor a 11 éves lányoknál $8 \%$, a fiúknál $13 \%$ a zaklatottak aránya, ami a vizsgált országok viszonylatában középmezőnyt vagy annál alacsonyabb helyezést jelent. A 15 éveseknél ezek az arányok sokkal alacsonyabbak (lányoknál 4\%, fiúknál 5\%), vagyis látható, hogy az áldozatok inkább a fiatalabbak közül kerülnek ki. Ellenkező irányú változás tapasztalható a zaklatók között, akiknek az aránya az életkorral nő. Amíg 11 évesen a megkérdezett magyar fiúk mindössze $3 \%$-a vallotta be, hogy legalább kétszer volt zaklatás elkövetője az elmúlt hónapokban, addig 15 évesen ez az arány már 10\% a 2005/2006-os kutatásban. Elszomorító, hogy a 2009/2010-es vizsgálatban éppen a legfiatalabb korosztály, a 11 éves fiúk adatai romlottak, ekkor 7\%-uk vallotta magát zaklatónak. A statisztikai adatok persze mindig csak egy pillanatfelvételt adnak, és sok-sok tényezőtől függnek. A számoknál érdekesebb azonban a zaklatás folyamata, valamint közege, az iskolai kultúra és klíma, amelyben a rendszeres bántalmazás megvalósulhat.

A zaklatás szereplői a zaklató(k), az áldozat(ok) és a néző(k) (Buda, 2008; ld. 1. ábra).

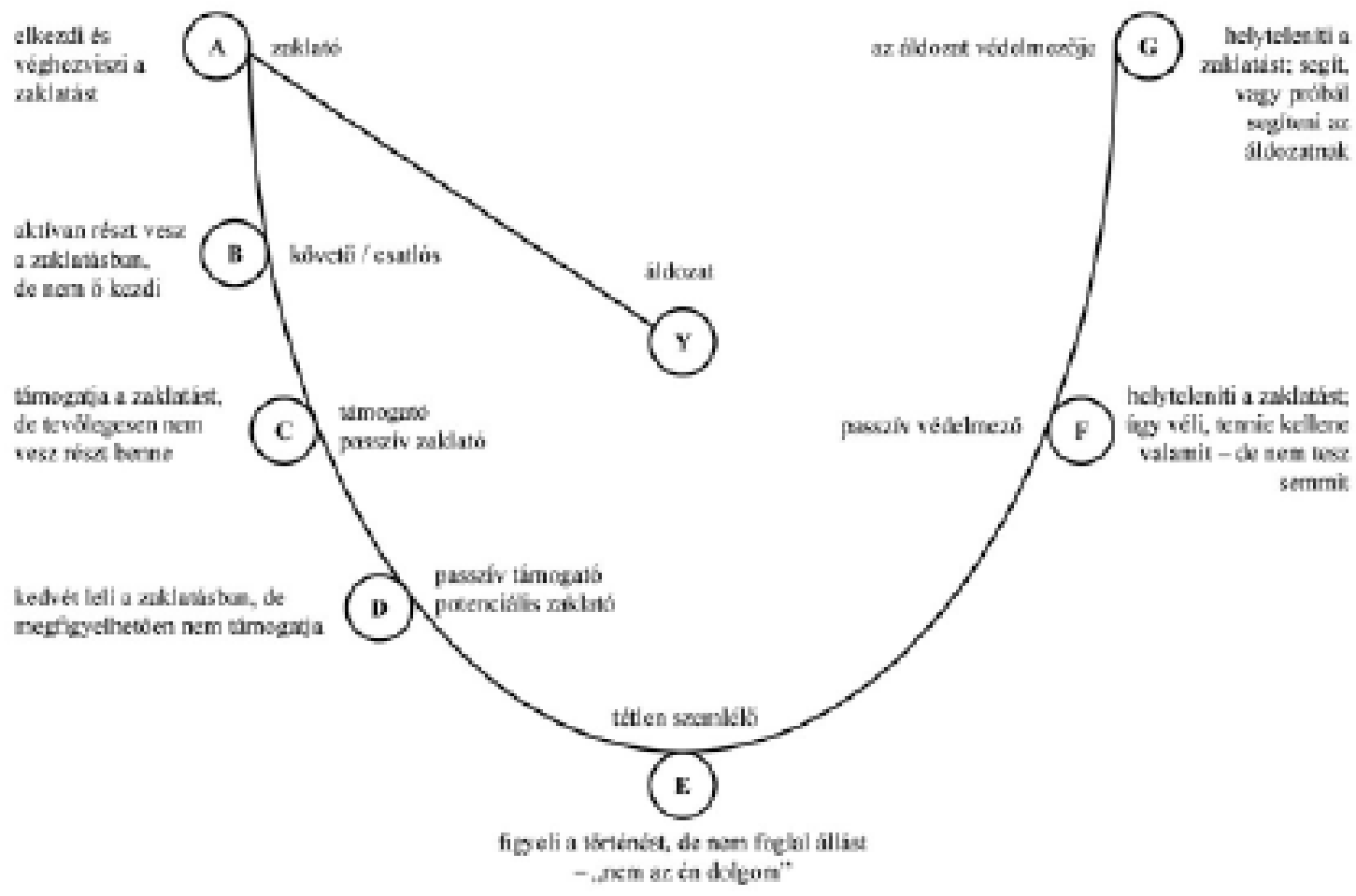

1. ábra: A zaklatás köre (Buda, Köszeghy és Szirmai, 2008) 
A zaklatók általában jó társas készségekkel, de alacsony empátiával és erős hatalmi ambícióval rendelkező gyerekek, akiknek családi hátterében inkább az elhanyagoló szülői magatartás figyelhető meg. Amint azt a fentiekben leírtuk, a népszerünek tartott gyerekek egy része agresszív, domináns, belölük könnyen válik zaklató. Főleg a zaklatás kapcsolati, szociális formája jelenik meg ezeknél a fiataloknál, a kirekesztés, barátok elcsábítása, rosszindulatú pletykák terjesztése. Nem meglepően ennek inkább a lányok a „mesterei”, míg a fiúk a lányoknál gyakrabban válnak zaklatókká fizikai vagy verbális erőszakot alkalmazva (Olweus, 1999).

Az áldozatok nagyon sokfélék lehetnek, és sok közösségben úgy tünik, hogy a kemény mag mindig talál magának valakit, akit áldozatául kiszemelhet (Buda, 2008). A passzív áldozat, a tipikus áldozat, általában visszahúzódó, gyenge, valamilyen mássággal rendelkezik, könnyű préda. A provokatív áldozat a zaklató-áldozat, aki maga is agresszív, sokszor gyenge társas képességekkel, alacsony státusszal jellemezhető. A szakirodalom adatai szerint ez a gyerekcsoport a leginkább veszélyeztetett a zaklatás lélektani következményei által. A lányok kapcsolati agressziójára nagyon sokszor jellemző, hogy a korábban legjobb barátnőjük ellen irányul. Ez a kislány látszólag érthetetlen okból válik áldozattá, azonban sokszor éppen a szoros kapcsolattal járó intimitás, a titkok megosztásával járó kiszolgáltatottság-érzés lesz a zaklatás indító oka, vagy a hasonlóság, a versengés.

A zaklatás legfontosabbnak tünő résztvevői a nézők, szemlélők, akik pozitív megerősítésükkel tartják fent a folyamatot. Nélkülük a zaklatásnak nem lenne értelme, nekik szól, hiszen a zaklató tőlük várja társas pozíciója megerősítését. Éppen ezért a zaklatás megelőzésében vagy megszüntetésében is rájuk, a szemlélődő többségre támaszkodva érhetünk el eredményeket. Ha a zaklatott gyermek a szemlélődők között támogatóra talál, akkor sokkal kevésbé sérül, mintha mindenki passzívan megerősíti a zaklatókat. Az áldozatokért kiálló, védelmező gyerekek magas empátiával, az anyához való biztonságos kötődéssel, énhatékonysággal, érzelmi stabilitással és zaklatás ellenes attitűdökkel jellemezhetők (Nagy, Körmendi és Pataky, 2012). A kutatások szerint ezen tényezők közül az empátia és a biztonságos kötődés emelkednek ki, azonban a támogató gyerekek egyéb jellemzői szintén nagyon fontosak. Hodges és munkatársai (1999) a barátságot mint az áldozattá válás elleni védőfaktort vizsgálva azt találták, hogy ugyan a legjobb baráttal rendelkezés általánosságban is csökkenti a zaklatás kockázatát, azonban a barátság minősége, a legjobb barát jellemzői befolyásolják ezt a védőhatást. Ha az áldozat legjobb barátja maga is „áldozat típus”, akkor hiába áll ki a barátjáért, inkább növekszik, mint csökken a zaklatás valószínüsége. Ugyanakkor ebben az esetben is fontos hangsúlyozni az észlelt társas támasz megerősítő funkcióját, ami véd a magány érzésével szemben.

A zaklatás minden résztvevő félre nézve negatív következményekkel jár. Legsúlyosabbak az áldozatra vonatkozó lélektani következmények, a szorongás, magány, önértékelési zavar, depresszió, pszichoszomatikus tünetek (Nansel et al. 2001, idézi Buda, 2009), melyek közül az önértékelési zavar és az ennek folyományaként létrejövő depresszív világlátás akár hosszú távon is fennmaradhat (Olweus, 1993). A legtöbb, a zaklatás időpontjában fennálló tünet azonban más közegbe kerülve, kilépve az áldozati szerepböl, megszűnik, a zaklatott fiatalok többsége felnövekedve egészséges és jó alkalmazkodó képességekkel rendelkező felnőtt lesz, nem különbözik a nem zaklatott fiataloktól. Nem igaz ez a zaklatókra, akik felnövekedve sokkal valószínübben válnak antiszociálissá, mutatnak viselkedési zavarokat, lesznek problémáik függőséget okozó szerekkel és válnak fiatalkori bűnelkövetőkké (Smith, 2000, idézi Buda, 2009). A zaklatás mindemellett rombolja a közösséget (Buda, Köszeghy és Szirmai, 2008), ugyanak- 
Társas kapcsolatok korunk iskolájában

kor elsősorban a közösségben és tágabb közegében, az intézményben értelmezhető és kezelhető probléma ${ }^{4}$.

\section{A társas kapcsolatokat befolyásoló intézményi meghatározók}

Az iskolák szervezeti kultúráját és klímáját hagyományos módon a benne dolgozó felnőttek, a vezetők és a pedagógusok szempontjából szokták vizsgálni (Serfőző, 2002, 2005), és sokkal kevesebb figyelem esik a szervezet jellemzőinek gyermekekre gyakorolt hatására, a kultúrának és klímának a társas kapcsolatok alakulásában betöltött szerepére. „A szervezeti kultúra a tagok által elfogadott, közösen értelmezett, mélyen beágyazódó értékek, attitüdök, meggyőződések, hiedelmek és normák rendszere; az intézményre jellemző viselkedésminták együttese" (Serfőző, 2005. 70. o.).

A kultúra többféle funkciót is betölt egy intézményben (Biró és Serfőző, 2003). Irányelvet nyújt, elvárásokat közvetít azzal kapcsolatban, hogy milyen viselkedés elfogadott, mivel lehet valaki népszerü vagy népszerütlen. Támpontot ad annak értelmezéséhez és értékeléséhez, hogy mi számít pozitív, hősies tettnek, eredménynek az iskolában. Növeli a kohéziót, összetartja a gyerekeket és pedagógusokat, akik érzelmi kapcsolatokat, támogatást, megerősítést biztosítanak egymás számára. Az elköteleződés, az azonosulás kialakulásában különösen fontos, megerősítő szerepe van a hagyományoknak, rituáléknak, ünnepeknek, a tanításon kívüli tevékenységeknek, iskolai programoknak.

Az iskolai kultúra építőkövei, a domináns értékek szólnak arról is, hogy mennyire fontos a közösség, a társas támogatás egy adott intézményben. A teamtípusú kultúra személyközpontú: fontos egymás elfogadása, a társas támogatás, az együttműködés, az összetartozás. Ezt megalapozzák és segítik a közös programok; érték és egyben cél a kohézió, az azonosulás erősítése. Ez a meghatározó intézményi értékrend hat az osztályok légkörére, a gyerekek társas kapcsolataira is. A teljesítményközpontú kultúrában az eredmények, a teljesítmény a meghatározó. Ez gyakran együtt jár a társas összehasonlítás előtérbe kerülésével, a fokozott versengéssel: gyakoriak a megmérettetések, versenyek, rangsorok. Az egyéni eredmények és teljesítmények hangsúlyozása negatívan hathat a gyerekek közötti társas kapcsolatokra, az együttmüködésre. Különösen igaz ez akkor, ha csak az intellektuális teljesítményeket ismerik el, és más erősségeket nem tartanak különösen értékesnek. A versengés sok gyereket ösztönöz, de sokakat elbizonytalanít, nagy a nyomás, erre oda kell figyelni a kortárskapcsolatokban. A sikeresség népszerüvé tehet gyerekeket, de ez az összemérésre épülö értékrend valószínűsítheti más szubkultúrák kialakulását is az intézményben, ahol a gyerekek éppen a nemkívánatos viselkedéssel, a követendő minták tagadásával próbálhatnak kitűnni. Az innovatív kultúra értékeli a kreativitást, az újszerü megoldásokat, jobban érvényesülhetnek az egyéniségek. Ez az értékrend támogathatja is a társas kapcsolatokat, mellőzheti a szabálykövetést, alá-fölérendeltséget, de az is lehet, hogy túlságosan az individuum kerül előtérbe és az összetartás háttérbe szorul. A szabályorientált kultúrában fontosak a jól meghatározott szerepek, a rend és a szabálykövetés, hagyománytisztelet. A tekintélyelvüség nem kedvez a felszabadult légkörnek, a túlzott autoritás fokozhatja a gyerekek közötti kapcsolatokban is a feszültséget, kedvez a bűnbakképzési folyamatoknak. (Baráth, 1998; Serföző és Somogyi, 2004)

\footnotetext{
${ }^{4}$ Itt most nem térünk ki az online zaklatás, vagy cyber-bullying kérdésére, melynek egyik lehetséges eleme az anonimitás, s a mely ez által nem köthetö intézményes háttérhez.
} 
Az iskola nagysága és a kortárskapcsolatok alakulásának összefüggését többen vizsgálták (Id. Szitó, 1991). A nagy intézmények személytelenebbek, a gyerekek gyakran maradnak névtelenek, a valamiben kiemelkedőket egyetlen érdeklődési körrel azonosítják, így a sokszínűség eltünik. A kisebb iskolákban nagyobb a személyesség, az iskolához és a kortársakhoz füződő kapcsolatok erősebbek, pozitívabbak. Nagyobb lehetősége van a gyerekeknek az osztálykereten kívül is megismerni egymást, szélesebb körben kibontakozhat az egyéniségük, specifikus tehetségük, könnyebben alakulhatnak ki a közös érdeklődésen alapuló barátságok.

Az iskolai klíma és a társas kapcsolatok minőségének együttjárása már sokkal inkább kutatott terület, különös tekintettel a kirekesztés és zaklatás problémájára. Az 1999-ben bekövetkezett tragikus littletoni események után, melyben két diák megölte tizenkét társát, egy tanárát, majd saját magát, kutatások, prevenciós és intervenciós programok egész sora indult az Egyesült Államokban, hogy megvizsgálják az iskolai agresszió légkörének sajátosságait, és segítsék azt átalakítani az elfogadás, együttmüködés és szeretet légkörévé (Id. Aronson, 2000; Wilson, 2004). A modern kutatások egyöntetűen alátámasztották Aronson és Bridgeman (1979) sokkal korábbi eredményeit az egymásrautaltság és konstruktív együttműködés szükségességéről az empátiát és elfogadást létrehozó klíma megteremtésében, mely kutatási eredményekre épül a ma már világszerte ismert Mozaik-módszer. Szintén összecsengenek a mai kutatások a klasszikus kutatásokkal az egyoldalú és erős versengés kapcsolatokat romboló hatásáról, melyet mindenki csak „cserkésztáboros” vagy „Rablóbarlang kísérletként” ismer (Id. Sherif, Harvey, White, Hood és Sherif, 1954/1961).

Az iskolai klíma, mint a társas kapcsolatok minőségét befolyásoló tényező tehát viszonylag korán belekerült a zaklatással foglalkozó kutatások érdeklődési terébe (Galloway, 1994), azonban megragadása és vizsgálata már korántsem olyan egyszerü. Magyarországon többek között Buda Mariann (2009) végzett kutatást az osztályklíma és zaklatás összefüggéseinek feltárására. Az ezerfős, kelet-magyarországi mintán végzett kérdőíves vizsgálat az osztálylégkör, mint az egyének közérzetén túlmutató, annak összegzett és átlagolt értékénél gazdagabb jellemző fontosságát bizonyította. A jó légkörrel bíró osztályokban az egyébként problémás viselkedésű gyermekek sem válnak feltétlenül zaklatóvá. Melyek lehetnek a jó légkör fontos összetevői? Az alacsony stressz szint és a jó hangulat mellett az olyan pozitív közösségi normák elfogadása, mint egymás tisztelete, segítségnyújtás, a gyengék védelmezése, a másság elfogadása. Az ezzel ellentétes ellenséges és versengő hangulat, amely a gyermekekben növeli az alap szorongásszintet, és rontja a problémamegoldás higgadt, nyertes-nyertes stratégiájának valószínűségét, valamint csökkenti az empátiás készséget és egymásra figyelést, megnöveli az iskolai zaklatás kialakulásának valószínüségét is. Természetesen a zaklatás maga is klímaalakító tényező, és a kutatások csak a korrelációt tudják feltárni, az ok-okozati viszonyokat nem tudják beazonosítani. Megfigyelhető emellett az osztálylégkör eltérő észlelése attól függően, hogy egy fiatal zaklató, áldozat vagy szemlélő szerepben van (Id. pl. Nagy, Körmendi és Pataky, 2012). Mindezek miatt az eredmények értelmezése, a légkör és a zaklatás kapcsolatának egyértelmű feltárása összetett probléma. Ugyanakkor azok az intervenciós kísérletek, zaklatás-megelőző programok, melyeket tudományosan terveznek és hatásvizsgálatokkal elemeznek, egyértelműen bizonyítják a pozitív klíma védőhatását a zaklatás kialakulásával vagy fennmaradásával szemben.

A pedagógus személye, különösen az alsó tagozaton, erős klímaalakító tényező. Csakúgy, mint a szülői nevelői stílusok esetén (Id. Baumrind, 1996), a pedagógus nevelői stílusával is összefüggésbe hozható a gyermekek fegyelmezettsége, szabálykövetése, 
egymás iránti szolidaritása és felelősségvállalása. Sullivan és munkatársai (2004) szerint, az autoritatív, vagyis a határokat felállító, és azokat következetesen érvényesítő, de a határokon belül nagyfokú szabadságot engedélyező pedagógiai hozzáállás bizonyul célravezetőnek a zaklatás megelőzésében. Mind az engedékeny, mind a tekintélyelvű (autoriter) megközelítés olyan légkört teremt, amely kedvez a zaklatásnak.

Az osztálytermi folyamatok irányítása, a tervezés, szervezés minősége szintén összefüggésbe hozható az osztály légkörének alakulásával. A jól kézben tartott, szorosan ellenőrzött, de szeretettel és gondoskodással vezetett osztályokban sokkal kisebb valószínűséggel jelenik meg a zaklatás, mint akár a kaotikus, fegyelmezetlen, akár a vasszigorral irányítottakban (Roland és Galloway, 2002).

A pedagógusok mellett ugyanakkor egyenrangúan fontos tényezőnek tűnik a kortársak rendszere, melyre építve és azt pozitív irányban fejlesztve a zaklatás légköre elkerülhető, és kialakítható a támogató iskolai közösség. A továbbiakban azokról a kortárssegítő lehetőségekről lesz szó, amelyeket nem kizárólagosan a zaklatás megelőzésére fejlesztettek ki, de természetesen támogatják ezt a célt. Nem tárgyaljuk ugyanakkor a zaklatás elleni programok (pl. az Olweus által kidolgozott OBPP) azon elemeit, melyek túlmutatnak a kortárskapcsolatok támogatásán.

\section{A kortársak mint támogatók, mentorok - a közösségek megerősítése}

A kortárssegítés gondolata az Egyesült Államokból kiindulva érkezett Európába, ahol országos szinten elsőként Finnország iskoláiban vezették be, 1972-ben (Kalland, 2011). A kortárssegítés rendszere az azonos korosztályhoz tartozók egymás iránti nyitottságán, bizalmán, elfogadásán, és a közösen osztott világlátás és tapasztalatok rendszerén alapul. A kortárssegítők olyan tanulók, akik szívesen segítenek másoknak és önkéntes alapon vesznek részt a közösség építésében. A finn iskolákban bevezetett rendszerben (és azokban az országokban, pl. Anglia, ahol ezt a módszertant adaptálták a helyi viszonyokra), ezek a fiatalok egy képzési programban vesznek részt, és folyamatosan biztosítják számukra a szupervíziót (Pihlaja és Tallgren, 2011). A rendszer felelös személyei ezáltal a felnőttek, akik általában egy segítő teamet alkotva támogatják a kortárssegítőket. A felnőtt támogatókat szintén felkészítik a feladatra, ezt Finnországban a Mannerheim Gyermekjóléti Liga (Mannerheimin Lastensuojeluliitto) szervezi. Angliában a finn mintára kialakított kortárssegítés rendszerét egy két éves pilot programban tesztelték nagy sikerrel. A Nemzeti Kortárssegítő Zaklatás Elleni Pilot (National Peer Mentoring Anti-Bullying Pilot) fő szervezője a lefordíthatatlan nevű Mentoring and Befriending Foundation, melynek célja a mentorálás és „barátkozás” támogatása, vagyis a közösségépítés, segítségnyújtás a legkülönbözőbb élethelyzetű személyeknek és közösségeknek. Hasonló szervezetek működnek és támogatják a kortárssegítés rendszerét Írországban is (Foróige). Magyarországon a kortárssegítés legkidolgozottabb rendszerével a felsőoktatásban és a terápiás önsegítő csoportok környékén találkozunk, és bár vannak általános- és középiskolai kezdeményezések, de azok egyediek, nincs átfogó, országos stratégia, hálózat és támogatási rendszer. Ahogyan Rácz József és Szabó Gabriella fogalmaznak: „A rendelkezésünkre álló információk alapján aligha beszélhetünk Magyarországon a „kortárs segítés" közös értelmezéséröl, minimális követelményeiről” (Rácz és Szabó, 2008. 34. o.), ezért nem lehetséges annak stratégiai megközelítése sem. A továbbiakban ezért a két legkidolgozottabb rendszerre, a finn Mannerheim Gyermekvédelmi Liga és az angol Mentoring and Befriending Foundation kortárs támogató rendszerére támaszkodva mutatjuk be a közösségépítés kortárssegítésen keresztül megvalósuló folyamatát, eszközeit, elérhető eredményeit (Pihlaja és Tallgren, 2011; MBF, 2011). 


\section{A kortárs támogatási program céljai}

A kortárssegítő programok céljai iskoláról iskolára mások lehetnek, illeszkedve az igényekhez, helyi adottságokhoz, a különböző résztvevők motivációihoz. A Mannerheim Liga által koordinált programok fő céljai ugyanakkor annyiban egységesek, amennyiben támaszkodnak a finn Közoktatási Törvény (1998) 2. paragrafusára, amely szerint a közoktatás célja „a tanulók támogatása, hogy a társadalom emberséges és erkölcsileg felelős tagjává válhassanak, és olyan ismeretek és képességek birtokában lehessenek, melyek szükségesek számukra az életben".

Ehhez igazodva a program céljai:

1. Az egymásra figyelő viselkedésformák támogatása - együttmüködő, barátságos légkör kialakítása; bizalom és biztonságérzet megteremtése, fejlesztése; egyenlő bánásmód érzetének segítése.

2. A tanulók iskolai bevonódásának segítése - a kulturális életben, demokratikus intézményekben való részvétel növelése; a tanár-diák együttmüködés előmozdítása.

3. A problémák proaktív megoldásának támogatása - iskolai zaklatás megelőzése és csökkentése; magányosság megelözés és csökkentés, drog-prevenció.

4. Személyes fejlődési utak támogatása - képzések, tematikus napok, melyek fejlesztik az empatikus és kommunikációs képességeket, felelősségérzetet, aktív állampolgárságot.

\section{A program mögött meghúzódó és általa támogatott értékek}

Egyenlőség - azt jelenti, hogy minden személy egyformán értékes. A programban megvalósuló tevékenységek segítik a tanulók önértékelésének növekedését, hogy önmagukat olyannak fogadják el, amilyenek.

Önkéntesség - a kortárs támogatás rendszere teljes egészében az önkéntességre épül. A programban segítőként részt vevő fiatalok és az őket támogató felnőttek egyaránt példát mutatnak a társadalmi felelősségvállalás, a közösségi munka területén.

Öröm - együtt dolgozni jó dolog! A kortárssegítők által koordinált programok megvalósítása csakúgy, mint az azokon való részvétel örömteli, ezáltal növeli a közösség összetartó erejét!

Bizalom - a kortárssegítők akkor müködnek hatékonyan, ha bizalmasan kezelik a rájuk bízott információkat. $A$ bizalmon túl azonban fontos a nehéz kérdésekkel való megbirkózásban annak érzete, hogy a segítő is számíthat segítségre, őt is támogatják más kortárssegítők és a felnőttek.

Fiatalság - a fiatalok saját életük szakértői, és joguk van a rájuk vonatkozó témákban hallatni a hangjukat. A kortárssegítő programok támaszkodnak erre a szakértelemre, értékként fogadva el a fiatalságot.

Részvétel és megerősödés - a kortárs támogató programba való bevonódás lehetőséget ad a tanulóknak annak megtapasztalására, hogy tevékenységeik által változást tudnak előidézni az iskolában és a tágabb közösségben. A kortárssegítők hidat képeznek a tanári kar és a tanulók között, segítve, hogy a diákok hallathassák hangjukat. Nem csak ők, de rajtuk keresztül a többi tanuló is megerősödhet demokratikus kompetenciáiban, saját sorsáért és a közösségért érzett felelösségében (Pihlaja és Tallgren, 2011). 


\section{A kortárs támogatás formái}

A kortárs támogatás nagyon sokféle formát ölthet. Az angol Mentoring and Befriending Foundation által kidolgozott programok közül az iskolák leggyakrabban a személyes mentorálás formáját használják (MBF, 2011). Ez egy viszonylag szoros bizalmi viszonyra épülő kapcsolat, ahol a mentor és a mentorált rendszeres alkalmanként (legalább hetente) találkoznak, hogy megvitassák mindazokat, amelyek a mentoráltat foglalkoztatják. Az állandó partneri viszony lehetővé teszi a bizalom, kiszámíthatóság, törődés érzetét. Ennek elérését egy kiválasztási folyamat is segíti, amelynek során a felnőtt segítők korra, nemre, kulturális háttérre, érdeklődésre való tekintettel próbálják megtalálni az egymáshoz illő mentort és mentoráltat ${ }^{5}$. A találkozókat általában az iskola erre kijelölt helyén tartják, a könyvtár és a büfé kedvelt helyszínek, de vannak olyan iskolák, ahol kifejezetten a mentorálás céljára tartanak fent egy kis, barátságos szobát, ahol mentor és mentorált a többiektöl zavartalanul tudnak beszélgetni.

A csoportos mentorálás sokszor megalapozza azt a viszonyt, amelyet a személyes mentorálás megkíván. Ilyenkor a mentoráltak kis csoportban találkoznak a mentorokkal, sokszor valamilyen konkrét aktivitással egybekötve. Az alsó-felső tagozat közötti vagy iskolaváltásnál jól bevált módszer a „kezdők” ilyen támogatott bevezetése az új közegbe.

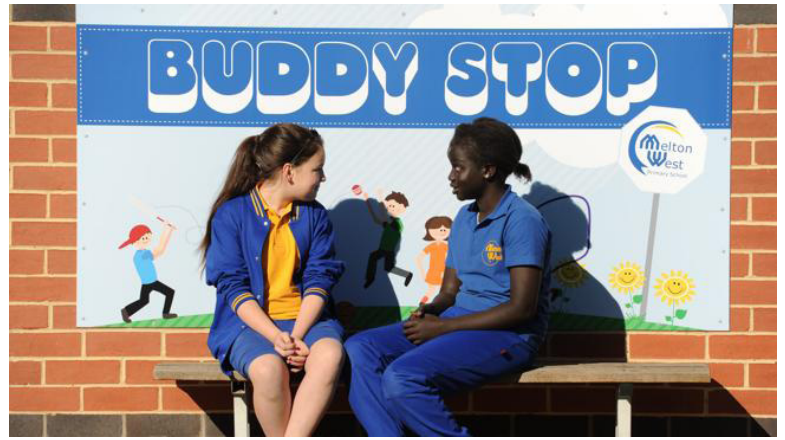

2. ábra: „Pajtás pad” a Melton West Primary Schoolban

A személyes mentorálás kevésbé formális változata a „beugró” mentorálás (drop-in session), ahol a mentorok ügyeleti rendben vannak beosztva, így valaki mindig elérhető. A módszer előnye éppen ez az informalitás, az iskolák ugyanakkor több energiát kell fordítsanak a „beugró” lehetőségének reklámozására. Azért, hogy ne legyen kihasználatlan a „beugró” mentor ideje és megtalálja azokat, akik segítségre szorulnak, de nem mernek segítséget kérni, sok iskolában körbejárnak a mentorok és megszólítják a csellengőket, magányosakat. Ez főleg az alsó tagozatosok esetén nagyon hasznos módszer.

Szintén a kicsiknél müködik a ,játszótárs” (buddy) vagy „baráti körök” rendszere, ahol a mentor jól megkülönböztethető ruhát visel, esetleg van egy pad vagy megálló tábla (Id. 2. ábra ${ }^{6}$ ), ahol ügyeletet tart, de itt is gyakori megoldás a játszótéren való körbejárás, hogy felfedezze és játékba hívja a magányosnak tűnő kicsiket. A kortárs segítő szervezhet programokat a játékidőre, felügyelheti az ebédelést és a folyosói/ udvari játékot, segíthet kibékíteni kisebb ellentéteket, melynek segítségével lecsökken a felnőttek beavatkozásának szükségessége, és fejlődik a gyermekek konfliktuskezelési képessége.

A kortárs mediáció a segítés egyik legmagasabb szintje, amelynek során a tanulók komplex konfliktuskezelési módszereket tanulnak meg és gyakorolnak saját és

\footnotetext{
5 Érdekességként itt említjük meg, hogy ez a fajta személyes mentorálás Finnországban már az óvodai rendszerben is megtalálható. Ismerősünk kisfiát 5 évesen választotta ki az óvóbácsi, hogy jó társas kompetenciái miatt legyen egy fiatalabb gyermek „segítő barátja”.

${ }^{6}$ Forrás: http://www.heraldsun.com.au/leader/west/buddy-stop-program-ensures-all-children-at-melton-west-primaryschool-have-someone-to-play-with/story-fngnvmj7-1226693463382?nk=ea8af8fc5bcaa4f52a3464d1c7e3e804
} 
egymás problémáinak megoldása céljából. A tanulók közötti konfliktus felmerülése esetén a kortárs segítők támogatják a probléma többszempontú feltárását és olyan megoldások kialakítását, melyet minden érintett fél el tud fogadni. A mentorok mint békéltetők járnak társaik között, példamutató magatartásuk ugyanakkor fejleszti a többiek társas és érzelmi képességeit is. A képzés során azonban azt is megtanulják, hogy melyek azok a bonyolult problémák, melyek megoldásához felnőtt segítségét kell kérniük. Az Egyesült Királyságban a kortárs mediációs technikák közül az egyik leggyakrabban használt módszer az ún. Helyreállító/Erősítő Megközelítések (Restorative Approaches $^{7}$ ) módszere, amely könnyen elsajátítható és az iskolákban jól kialakítható konfliktuskezelési és megelőzési programot jelent, melynek célja olyan légkör kialakítása, ahol mindenkit meghallgatnak, mindenkit tisztelnek, mindenkinek az igényeire figyelnek.

Végül meg kell említsük a XXI. század Z-generációjának kihívásaira reagáló "cyber mentor" fogalmát, aki abban segíti társait, hogy az internetet és online eszközöket biztonsággal és egymást tiszteletben tartva használják. Ez a feladat a mobil eszközök korában mindenképpen nehezebb, mint észrevenni a magányosokat a játszótéren. A mentorálás legnagyobb kihívásának megoldása újabb módszerek, információtechnológiai alkalmazások kialakítását igényli ${ }^{8}$.

\section{A kortárssegítő programok eredményei}

A rendszer szinten bevezetett és kutatások által monitorozott kortárs támogató rendszerek eredményességét számos mutató igazolja (Id. MBF, 2011). A Mentoring and Befriending Foundation 2008-2010 közötti pilot programjának értékelő jelentése szerint, amelyben 150 iskola 6000 mentora és többször annyi mentoráltja adatait használták fel, a legtöbbször zaklatott fiatalok 63\%-a érezte úgy, hogy a mentorálás eredményeként lényegesen csökkent az áldozattá válás gyakorisága egy év alatt. A leginkább veszélyeztetett fiatalok életminősége jelentősen javult, $62 \%$-uk eredményei közelebb kerültek a nem veszélyeztetett „átlag”-hoz a mentorálás 1 éve után. A projektben részt vevő tanulók több mint 75\%-a érezte úgy, hogy növekedett önbizalma a kortárssegítési programban. A legnagyobb változást az önértékelésben és a többiekhez való kötődés, kapcsolódás érzete mértékében tapasztalták a kutatók, utóbbi 77\%-kal nőtt.

A 2009-2010 közötti MBF projekt további adatokat szolgáltat a kortárssegítés pozitív hatásairól. A projektben részt vevő mentorok és mentoráltak esetén is csökkent az iskolai hiányzások száma, és jobban növekedett az iskolai teljesítmény, mint azoknál az osztálytársaknál, akik nem vettek részt a programban. Mentorok és mentoráltak a nem részt vevő fiataloknál jobb eredményeket értek el a jóllét mutatóiban és a magatartás megítélésében.

Összegezve, minden vizsgált mutatóban fejlődést találtak a kutatások, ám ezek mértéke néhol nem túl nagy. Az biztos, hogy a program beváltotta a hozzá füzött reményeket, azonban energia és időigényessége sok iskolát visszatart a bevezetéstől (bővebben Id. MFB, 2011).

\footnotetext{
7 https://www.youtube.com/watch?v=tH7tn4vHmyM

8 A BeatBullying Cyber Mentor programja az egyike volt ezeknek a kezdeményezéseknek, amely nemzetközi szintéren is meghatározóvá vált az internetes zaklatás elleni harcban. Sajnálatos módon a szervezet 2014 októberében, pénzügyi okok miatt befejezte müködését.
} 


\section{Zárszó}

Nézetünk szerint - bár erre nincsenek longitudinális kutatásokból származó bizonyítékaink - korunk gyermekei társas kapcsolatai nem változtak annyit, mint gondolnánk. Régen is voltak "nemecsekek” (kis betűvel) és Ács Ferik, közlegények, akik könnyen váltak áldozattá és kapitányok, akikre mindenki felnézett. Régen is szerették és bántották, segítették és gáncsolták egymást a gyerekek, csak ma sokkal jobban odafigyelünk a gyermekek világára. A kortársi kapcsolatok kutatások tárgyává lettek és nyilvánosságot kapnak, ezért mindenkinek van róla benyomása, szülőként és pedagógusként akár saját tapasztalata is. Az elmúlt korok pedagógiai gyakorlatával szemben azonban a mai kor pedagógusainak sokkal több eszköz, kidolgozott módszer, kipróbált és bevált program áll a rendelkezésére, hogy a gyermekek társas kapcsolatait a nevelés céljainak és a gyermekek jóllétének előmozdítására alakítsa.

Reméljük, az itt leírtak is segítenek abban, hogy „ezeket a mai fiatalokat” jobban megértsük és hatékonyabban tudjuk útjukon segíteni.

\section{Irodalom}

Adler, P. A. \& Adler, P. (1998): Peer power: Preadolescent culture and identity. Rutgers University Press, New Brunswick, NJ.

Aronson, E. \& Bridgeman, D. (1979): Jigsaw groups and the desegregated classroom: In pursuit of common goals. Personality and Social Psychology Bulletin, Vol 5 (4), 438-446.

Aronson, E. (2000): Nobody left to hate: Teaching compassion after Columbine. Freeman, W. H. \& Company (magyarul: Columbine után. Az iskolai erőszak szociálpszichológiája. Ab Ovo, 2009)

Baráth Tibor (1998): A közoktatás hatékonysága. In: Balázs Éva (szerk.): Iskolavezetők a 90-es években. Országos Közoktatási Intézet, Okker, Budapest, 135-172.

Baumrind, D. (1996): The discipline controversy revisited. Family Relations, 45 (4), 405-414.

Biró Balázs és Serföző Mónika (2003): Szervezetek és kultúra. In: Hunyady György és Székely Mózes (szerk.): Gazdaságpszichológia. Osiris, Budapest, 481-541.

Bronfenbrenner, U. (1979): The Ecology of Human Development: Experiments by Nature and Design, Harvard University Press, Cambridge, MA.

Buda Mariann (2008): Iskolai erőszak, iskolai zaklatás. Fordulópont, 2008/3. 11-25.

Buda Mariann (2009): Közérzet és zaklatás az iskolában. Iskolakultúra 2009/5-6, 3-15.

Buda Mariann, Kőszeghy Attila és Szirmai Erika (2008): Iskolai zaklatás - az ismeretlen ismerős. Educatio, 3. 373-386.

Cillessen, A. H. N. \& Mayeux, L. (2004): From censure to reinforcement: Developmental changes in the association between aggression and social status. Child Development, 75, 147-163.

Cillessen, A. H. N. \& Rose, A. J. (2005): Understanding popularity in the peer system. Current Directions in Psychological Science, Vol. 14 (2), 102-105.

Galloway, D. (1994): Bullying: The importance of a whole school approach. Therapeutic Care \& Education, 1. 19-26.

Harter, S. (2006): The development of self-representations in childhood and adolescence. In W. Damon \& R. Lerner (Eds.), Handbook of child psychology (6th ed.). Wiley, New York.

Hawley, P.H. (2003): Prosocial and coercive configurations of resource control in early adolescence: A case for the well-adapted Machiavellian. Merrill-Palmer Quarterly, 49, 279-309.

Heyman, G. D, Fu, G. \& Lee, K. (2008): Reasoning about the disclosure of success and failure to friends among children in the United States and China. Developmental Psychology. 2008; 44, 908-918. 
Hodges, E. V. E, Boivin, M., Vitaro, F. \& Bukowski, W. M. (1999): The power of friendship: Protection against an escalating cycle of peer victimization. Developmental Psychology. 1999; 35, 94-101.

Inhelder, B. és Piaget, J. (1967): A gyermek logikájától az ifjú logikájáig: A formális müveleti struktúrák kialakulása. Akadémiai Kiadó, Budapest.

Kalland, M. (2011): Foreword. In Pihlaja, K. \& Tallgren, S. (Eds., 2011). Setting up peer support programmes in schools - a step-by-step guide. Mannerheim League for Child Welfare, Helsinki, Finland.

LaFontana, K.M. \& Cillessen, A.H.N. (2002): Children's stereotypes of popular and unpopular peers: A multi-method assessment. Developmental Psychology, 38, 635-647.

Lease, A. M., Kennedy, C. A. \& Axelrod, J. L. (2002): Children's Social Constructions of Popularity. Social Development, 11: 87-109.

Mérei Ferenc (1996). Közösségek rejtett hálózata. Osiris Kiadó, Budapest.

Mészáros Aranka (1998): Az osztály csoportszerkezete és hatékonysága. Iskolakultúra 1998/11, 3-21.

MFB (2011): Peer Mentoring in Schools. A review of the evidence base of the benefits of peer mentoring in schools including findings from the MBF Outcomes Measurement Programme. Mentoring and Befriending Foundation. http://www.mandbf.org/wp-content/ uploads/2011/10/Peer_Mentoring_in_Schools1.pdf

Nagy Ildikó, Körmendi Attila, Pataky Nóra (2012): A zaklatás és az osztálylégkör kapcsolata. Magyar Pedagógia, 112. évf. 3. szám 129-148.

Nansel, T. R., Overpeck, M., Pilla, R. S., Ruan, W. J., Simons-Morton, B. \& Scheidt, P. (2001): Bullying behaviors among U.S. youth: Prevalence and association with psychosocial adjustment. Journal of the American Medical Association, 16. 2094-2100.

Newcomb, A. F., Bukowski, W. M., \& Pattee, L. (1993). Children's peer relations: A metaanalytic review of popular, rejected, neglected, controversial, and average sociometric status. Psychological Bulletin, 113. 99-128.

Olweus, D. (1993): Victimization by peers: Antecedents and long-term outcomes. In K. H. Rubin, \& J. B. Asendorf (Eds.), Social withdrawal, inhibition, and shyness in childhood. Erlbaum, Hillsdale, NJ, 315-342.

Olweus, D. (1999): Iskolai zaklatás. Educatio, 1999/4, 717-739. o.

Parker, J. G. \& Gottman, J. M. (1989): Social and emotional development in a relational context: Friendship interaction from early childhood to adolescence. In Berndt, T. J. \& Ladd, G. W. (Eds), Peer relationships in child development. Wiley series on personality processes. (pp. 95-131). Oxford, England: John Wiley \& Sons.

Parker, J. G., Rubin, K. H.; Erath, S. A.; Wojslawowicz, J. C. \& Buskirk, A. A. (2006): Peer relationships, child development, and adjustment: A developmental psychopathology perspective. .In Cicchetti, D. \& Cohen, D. J. (Eds), Developmental psychopathology, Vol 1: Theory and method (2nd ed.), (pp. 419-493). Hoboken, NJ, US: John Wiley \& Sons Inc.

Parkhurst, J. T. \& Hopmeyer, A. (1998): Sociometric popularity and peer-perceived popularity: Two distinct dimensions of peer status. Journal of Early Adolescence, 18. 125-144. doi:10.1177/0272431698018002001

Pihlaja, K. \& Tallgren, S. (Eds., 2011). Setting up peer support programmes in schools - a step-by-step guide. Mannerheim League for Child Welfare, Helsinki, Finland.

Rácz József és Szabó Gabriella (2008): A kortárs és sorstárs segítés módszere. In Rácz József (szerk.): Az esélyteremtés új útjai. A kortárs és sorstárs segítéssel szerzett tapasztalataink. L'Harmattan Kiadó, Budapest, 12-52.

Rodkin, P.C., Farmer, T.W., Pearl, R., \& Van Acker, R. (2000): Heterogeneity of popular boys: Antisocial and prosocial configurations. Developmental Psychology, 36. 14-24.

Roland R., \& Galloway, D. (2002). Classroom influences on bullying. Educational Research, 44 (3). 299-312.

Rose, A. J. \& Swenson, L. P. (2009): Do perceived popular adolescents who aggress against others experience emotional adjustment problems themselves? Developmental Psychology 45 (3), 868-872. 
Rose, A.J., Swenson, L.P., \& Waller, E.M. (2004): Overt and relational aggression and perceived popularity: Developmental differences in concurrent and prospective relations. Developmental Psychology, 40. 378-387.

Rubin, K. H., Bukowski,W. M., \& Parker, J. G. (1998): Peer interactions, relationships, and groups. In W. Damon (Series Ed.) \& N. Eisenberg (Vol. Ed.), Handbook of child psychology: Vol. 3. Social,emotional, and personality development (5th ed.). Wiley, New York, pp. 619-700.

Ruble, D. N., Boggiano, A. K., Feldman, N. S. \& Loebl, J. H. (1980): Developmental analysis of the role of social comparison in self-evaluation. Developmental Psychology, Vol 16 (2), $105-115$.

Santrock, J. W. (2009): Educational Psychology. 4th Edition. McGraw-Hill, London.

Selman, R. L. \& Byrne, D.F. (1974): „A structural-developmental analysis of levels of role taking in middle childhood". Child Development 45. 803-806.

Serfőző Mónika (2002): A szervezeti kultúra fogalmának, modelljeinek értelmezése az óvodában, iskolában. In: Mészáros Aranka (szerk.): Az iskola szociálpszichológiai jelenségvilága. ELTE Eötvös Kiadó, Budapest, 495-525.

Serfőző Mónika (2005): Az iskolák szervezeti kultúrája. Iskolakultúra, 2005/10, 70-83.

Serfőző Mónika és Somogyi Mónika (2004): Az iskola mint szervezet. In: N. Kollár Katalin Szabó Éva (szerk.): Pszichológia pedagógusoknak. Osiris Kiadó, Budapest, 451-471.

Sherif, M., Harvey, O. J., White, B. J., Hood, W. R. \& Sherif, C. W. (1954/1961): Intergroup conflict and cooperation: The Robbers Cave experiment. (Vol. 10). Norman, OK: University Book Exchange. http://psychclassics.yorku.ca/Sherif/index.htm (letöltés 2014.09.22.)

Smith, R. L., Rose, A. J. \& Schwartz-Mette, R. A. (2010): Relational and overt aggression in childhood and adolescence: Clarifying mean-level gender differences and associations with peer Acceptance. Social Development, 19: 243-269.

Sullivan, K., Cleary, M., \& Sullivan, G. (2004). Bullying in secondary schools: What it looks like and how to manage it. Thousand Oaks, CA: Corwin Press.

Szitó Imre (1991): Az ökológiai megközelítés az iskolában. Magyar Pszichológiai Szemle, 1991/2. szám, 215-231.

Thompson, R. (1991): Emotional regulation and emotional development. Educational Psychology Review, Vol.3 (4). 269-307.

Wilson, D. (2004): The Interface of School Climate and School Connectedness and Relationships with Aggression and Victimization. Journal of School Health, 74. 293-299. 